Pesq. Vet. Bras. 35(4):329-336, abril 2015 DOI: $10.1590 /$ S0100-736X2015000400003

\title{
Histophilus somni-induced thrombotic meningoencephalitis in cattle from northern Paraná, Brazil ${ }^{1}$
}

\author{
Selwyn A. Headley ${ }^{2 *}$, Ana Paula F.R.L. Bracarense ${ }^{2}$, Victor H.S. Oliveira ${ }^{3}$, Gustavo R. \\ Queiroz ${ }^{4}$, Werner Okano $^{5}$, Alice F. Alfieri ${ }^{3}$, Karina K.M.C. Flaiban' ${ }^{6}$, Júlio A.N. Lisbôa ${ }^{4}$ \\ and Amauri A. Alfieri ${ }^{3}$
}

\begin{abstract}
Headley S.A., Bracarense A.P.F.R.L., Oliveira V.H.S., Queiroz G.R., Okano W., Alfieri A.F., Flaiban K.K.M.C., Lisbôa J.A.N. \& Alfieri A.A. 2015. Histophilus somni-induced thrombotic meningoencephalitis in cattle from northern Paraná, Brazil. Pesquisa Veterinária Brasileira 35(4):329-336. Laboratório de Patologia Animal, Departamento de Medicina Veterinária Preventiva, Universidade Estadual de Londrina, Rodovia Celso Garcia Cid, PR-445 Km 380, Cx. Postal 10.011, Londrina, PR 860571-970, Brazil. E-mail: selwyn.headley@uel.br

Thrombotic meningoencephalitis (TME) is a fatal neurological disease of cattle, predominantly from North America, that is caused by Histophilus somni with sporadic descriptions from other countries. This manuscript describes the occurrence of spontaneous TME in cattle from northern Paraná, Brazil. Most cattle had acute neurological manifestations characteristic of brain dysfunction. Hematological and cerebrospinal fluid analyses were not suggestive of bacterial infections of the brain. Histopathology revealed meningoencephalitis with vasculitis and thrombosis of small vessels that contained discrete neutrophilic and/or lymphocytic infiltrates admixed with fibrin at the brainstem, cerebral cortex, and trigeminal nerve ganglion of all animals. All tissues from the central nervous system used during this study were previously characterized as negative for rabies virus by the direct immunofluorescence assay. PCR and RT-PCR assays investigated the participation of infectious agents associated with bovine neurological disease by targeting specific genes of $\mathrm{H}$. somni, Listeria monocytogenes, bovine herpesvirus -1 and -5 , bovine viral diarrhea virus, and ovine herpesvirus-2. PCR and subsequent sequencing resulted in partial fragments of the $16 \mathrm{~S}$ rRNA gene of H. somni from brain sections of all animals with histopathological diagnosis of TME; all other PCR/RT-PCR assays were negative. These findings confirmed the participation of $H$. somni in the neuropathological disease observed in these animals, extend the geographical distribution of this disease, and support previous findings of $H$. somni from Brazil.
\end{abstract}

INDEX TERMS: Histophilus somni, thrombotic meningoencephalitis, bovine disease, neuropathology, central nervous system, molecular diagnostics, histophilosis.

RESUMO.- [Meningoencefalite trombótica-induzida por Histophilus somni em bovinos da região norte do Paraná.] Meningoencefalite trombótica (Thrombotic meningo-

\footnotetext{
${ }^{1}$ Received on October 3, 2014.

Accepted for publication on February 10, 2015

${ }^{2}$ Laboratório de Patologia Animal, Departamento de Medicina Veterinária Preventiva, Universidade Estadual de Londrina (UEL), Londrina, PR, 860571-970, Brasil.*Corresponding author: selwyn.headley@uel.br

${ }^{3}$ Laboratório de Biologia Molecular, Departamento de Medicina Veterinária Preventiva, UEL, Londrina, PR 860571-970.

${ }^{4}$ Clínica de Grande Animais, Departamento de Clínicas Veterinárias, UEL, Londrina, PR, 860571-970.

${ }^{5}$ Laboratório de Patologia Animal, Escola de Medicina Veterinária, Universidade Norte do Paraná, Arapongas, PR, 86702-670, Brasil.

${ }^{6}$ Laboratório de Patologia Clínica, Departamento de Medicina Veterinária Preventiva, UEL, Londrina, PR 860571-970.
}

encephalitis- TME) é uma doença neurológica fatal de bovinos ocasionada por Histophilus somni. A infecção tem sido descrita predominantemente na América do Norte e de forma esporádica em outros países. 0 objetivo deste estudo é relatar a ocorrência de TME em bovinos da região norte do estado do Paraná, Brasil. A maioria dos animais apresentaram sinais clínicos neurológicos característicos de disfunção cerebral aguda. Análises hematológicas e do fluido cerebrospinal não foram sugestivas de infecção bacteriana do cérebro. A histopatologia revelou meningoencefalite com vasculite e trombose de pequenos vasos com discreto infiltrado neutrofílico e/ou linfocítico mesclada com fibrina no tronco e córtex cerebral e no gânglio do nervo trigêmio de todos os animais. As amostras de sistema nervoso central incluídas nesse estudo foram previamente caracterizadas 
como negativas para raiva por meio de técnica de imunofluorescência direta. A participação de agentes infecciosos associados à doença neurológica em bovinos foi avaliada por técnicas moleculares como PCR e RT-PCR para amplificação parcial de genes de H. somni, Listeria monocytogenes, herpesvírus bovino 1 e 5 , vírus da diarreia viral bovina e herpesvírus ovino 2. As seções do cérebro de todos os animais com diagnóstico histopatológico de TME foram positivas em PCR para a detecção do gene 16S rRNA de H. somni. $\mathrm{O}$ sequenciamento dos produtos amplificados confirmou a presença de DNA de H. somni nos fragmentos de cérebro avaliados. As reações de PCR/RT-PCR para todos os outros micro-organismos avaliados resultaram negativas. Os resultados desse estudo confirmaram a participação do $H$. somni nos episódios de doença neurológica observada nos animais avaliados, amplia a distribuição geográfica da TME e ratifica estudos prévios realizados no Brasil que demonstraram a presença de H. somni em outras formas de manifestação clínica das infecções por essa bactéria.

TERMOS DE INDEXAÇÃO: Meningoencefalite trombótica, Histophilus somni, doença de bovinos, neuropatologia, sistema nervoso central, diagnóstico molecular, histofilose.

\section{INTRODUCTION}

Histophilosis is a multisystemic disease entity of ruminants caused by the Gram-negative bacterium Histophilus somni (formerly known as Haemophilus somnus) which produces several clinical syndromes including thrombotic meningoencephalitis (TME), bronchopneumonia, pleuritis, polysynovitis, septicemia, myocarditis, otitis media, infertility, abortion, and mastitis (Inzana \& Corbeil 2004, Pérez et al. 2010). Histophilosis has been a major problem of cattle in North America (Van Dreumel et al. 1970, MacDonald et al. 1973, George 2009) and Australia (Lancaster et al. 1984, Hick et al. 2012) for decades, resulting in severe economic loss to the affected livestock industry (Saunders et al. 1980). Additionally, there are sporadic reports of histophilosis from countries such as the UK (Wessels \& Wessels 2005), Argentina (Descarga et al. 2002), and Japan (Tanaka et al. 2005). Recently, we have described histophilosis in cattle from different geographical regions of Brazil due to the characterization of systemic disease in five animals (Headley et al. 2013b), and reproductive manifestations have been confirmed in bovine fetuses (Headley et al. 2015). Further, we believe that histophilosis might be a threat to the beef cattle feedlot industry of Brazil and South America (Headley et al. 2014a), while H. somni is considered as an emerging disease pathogen of beef cattle feedlots in Argentina (Descarga et al. 2002).

TME is a fulminating neurological disease of cattle that occurs after septicemia induced by H. somni (George 2009), which produces fatality rates in affected herds and affects predominantly feedlot cattle relative to dairy or pastured animals (Fecteau \& George 2004). Affected cattle can demonstrate lateral recumbency, profound depression, a sleepy appearance (MacDonald et al. 1973; Fecteau \& George 2004), head tilt, nystagmus, strabismus, blindness, coma, and convulsions (MacDonald et al. 1973, George 2009).
Gross neurological lesions are characteristic and visible in most untreated cases, and consist of $1-30 \mathrm{~mm}$ diameter hemorrhagic areas randomly distributed throughout the brain (Van Dreumel et al. 1970, Maxie \& Youssef 2007, Zachary 2012). Histologically, TME is characterized by vasculitis and thrombosis, which predominantly affects small arteries, resulting in tissue necrosis with a marked neutrophilic response (Inzana \& Corbeil 2004, Maxie \& Youssef 2007, George 2009); thrombi frequently contains intralesional bacterial colonies (Maxie \& Youssef 2007, Zachary 2012). This paper presents the clinical, hematological, cerebrospinal fluid, and neuropathological findings observed in cases of $H$. somni-induced thrombotic meningoencephalitis from northern Paraná.

\section{MATERIALS AND METHODS}

Animals, clinical history, and necropsy. All affected cattle originated from several breeds, and between 1.5-6 years of age; the signalment and principal clinical manifestations of the affected cattle are given in Table 1. Further, these animals were part of an ongoing study that is investigating the cause of neurological disease in cattle from the state of Paraná. Most properties $(n=4)$ were small subsistence farms, while herd no 5 raised cattle for fattening. Cattle at all herds are routinely vaccinated against Foot and Mouth Disease and clostridiosis, maintained predominantly on green pastures, and supplemented with commercially prepared mineral salts; water was given ad libitum.

The first two cases occurred in late July 2013, with the other three cases occurring during August, September, and December 2013. All animals were depressed, but most $(n=4)$ were in permanent recumbency, a few were blind $(n=2)$, and with convulsions $(n=2)$; only one animal was febrile ( $\left.\mathrm{n}^{\circ} 1\right)$. The course of clinical manifestations until spontaneous death or euthanasia was acute in most cases $(n=4)$, with variation of 2 to 8 days, but animal $n^{0}$ 2 was reportedly ill during 22 days. This animal was hospitalized due to a history of progressive emaciation and muscular weakness, and was maintained on supportive therapy. Additionally, most animals $(n=4)$ were euthanized in extremis, with owners consent, due to the severity of clinical manifestations; animal no 4 died spontaneously. Blood samples and cerebrospinal fluid (CSF) of all animals were collected before death for laboratory analyses.

Routine necropsies were performed soon after death; selected tissue fragments (brain, liver, lungs, kidneys, spleen, intestine, myocardium, and lymph nodes) from each animal necropsied were fixed by immersion in $10 \%$ buffered formalin solution and routinely processed for histopathological evaluation. Neurological tissue fragments of all animals were obtained from five pre-defined anatomical locations of the brain: brainstem, cerebrum, cerebellum, thalamus, and the trigeminal nerve ganglion and the carotid rete miriabile (TNG-CRM) complex. Duplicate sections of the organs mentioned above were collected freshly during necropsy, and maintained at $-80^{\circ} \mathrm{C}$ until processed for molecular diagnostics. Additionally, to avoid cross contamination, necropsy equipment used for sample collection were cleaned and then immersed in a mixture of antiseptic and disinfectant solution between each collected sample.

This study adhered to the guidelines for the usage of animals/ samples in studies as required by CONCEA (approved by CEUA/ UEL protocol \# 32340.2012.04).

Characterization of rabies virus. The direct immunofluorescence assay was performed for the identification of Lyssavirus from brain samples of all animals submitted to the Official Dia- 
Table 1. Signalment, principal clinical manifestations, and outcome of cattle with thrombotic meningoencephalitis from the northern Paraná

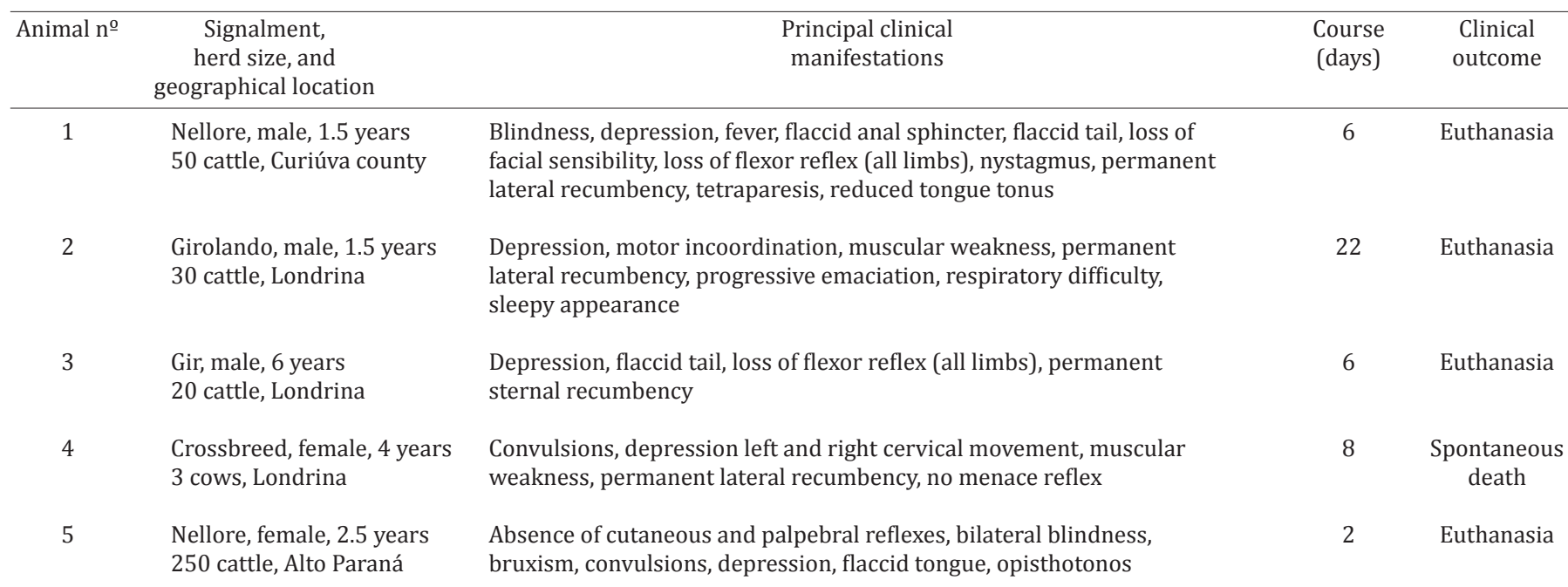

gnostic Laboratory (Centro de Diagnóstico Marcos Enrietti; Curitiba, Paraná, Brazil).

PCR/RT-PCR characterization of infectious agents associated with neurological disease in cattle. Nucleic acids were extracted from frozen brain fragments (cerebrum, cerebellum, brainstem, TNG, and thalamus) of all animals as described (Boom et al. 1990), in association with Proteinase K (Ambion, Grand Island, NY, USA), and a modified method (Alfieri et al. 2006), and then used in PCR/RT-PCR assays designed to identify infectious agents associated with neurological disease of cattle from Brazil. These protocols targeted specific amplicons of the glycoprotein $\mathrm{C}$ gene of bovine herpesvirus type 1 (BoHV-1) and -5 (Claus et al. 2005), and the 5'-UTR region of the bovine viral diarrhea virus (Vilček et al. 1994), the listeriolysin gene of Listeria monocytogenes (Wesley et al. 2002), the 16s rRNA gene of Histophilus somni (Angen et al. 1998). The tegument protein gene of ovine herpesvirus type $2(\mathrm{OvHV}-2)$ was also targeted to detect DNA of sheep-associated malignant catarrhal fever, SA-MCF (Baxter et al. 1993).

Positive controls consisted of extracted nucleic acid from prototype strains of BoHV-1 (Los Angeles) and -5 (AA-Par) amplified in Madin-Darby bovine kidney cells (Claus et al. 2005); and field strains of previous cases of OvHv-2 (Headley et al. 2013c), L. monocytogenes (Headley et al. 2013a; Headley et al. 2014b), H. somni (Headley et al. 2013b), and OvHV-2 (Headley et al. 2013c). Nuclease-free water (Invitrogen Corp., Carlsbad, CA, USA) was used as negative controls in all PCR/RT-PCR assays. All RT-PCR/PCR products were separated by electrophoresis in $2 \%$ agarose gels, stained with ethidium bromide, and examined under ultraviolet light.

Sequencing and phylogenetic analyses. The amplified PCR products were then purified (illustra GFX PCR DNA and Gel Band Purification Kit, GE Healthcare, Little Chalfont, Buckinghamshire, UK) and submitted for direct sequencing using the forward and reverse primers. The obtained sequences were examined for quality analysis of chromatogram readings by using the PHRED software (http://asparagin.cenargen.embrapa.br/phph); sequences were only accepted if base quality was equal to or greater than 20 . Consensus sequences were then generated by the CAP3 program (http://asparagin.cenargen.embrapa.br/cgi-bin/phph/cap3. pl), after which the partial nucleotide sequences obtained were compared by the BLAST program (http://www.ncbi.nlm.nih.gov/ BLAST) with similar sequences deposited in GenBank to confirm sequence identity and validate the isolates identified. The partial nucleotide sequences of $H$. somni obtained during this investigation were deposited at GenBank.

Phylogenetic trees and sequence alignments were created by using MEGA 6.01 software (Tamura et al. 2011), constructed by the Neighbor-Joining method, based on 1,000 bootstrapped data sets of the nucleotide sequences of selected strains of the 16S rRNA gene of Pasteurellaceae family; distances values were calculated by using the Kimura 2 parameter model.

\section{RESULTS}

\section{Hematological and biochemical analyses of blood and cerebrospinal fluid}

Overall CSF analysis from all animals did not indicate definite bacterial infections, but there were variations to the complete blood cell count (CBC) of these animals. Hematological analyses revealed (Table 2) neutrophilia in all animals; hyperfibrinogenemia (animals $n \div 3$ and 4), and leucocytosis (no 2) were observed. Significant biochemical abnormalities included elevated urea concentration ( $\mathrm{n}$ o 1 and 5), with increased enzymatic activity of creatine kinase ( $n-1,3-5)$, aspartate aminotransferase ( $\mathrm{n}-1-4)$, and alkaline phosphatase ( $\mathrm{n}-1,2$ and 5 ). CSF alterations were observed only in animal no 5 and consisted of hyperproteinorraquia and mononuclear pleocytosis (Table 3 ).

\section{Pathological findings}

The most constant gross neurological alterations observed in these animals were moderate congestion of meningeal vessels $(n=3)$, shallow sulci with distended gyri $(n=2)$, and foci of hemorrhage at the cerebral cortex of animal $\mathrm{n}^{\mathrm{o}}$ 4 (Fig. 1A-B); significant pathological findings were not observed in animal no 5 (Table 4).

Histologically, thrombi occurred predominantly within small vessels of the meninges and in all regions of the brain (Fig. 1C-E) of all animals investigated; the distribution of TME within the brain sections of these animals is given in Table 4. Briefly, TME was observed at the cerebral cortex $(n=5)$, cerebellar white matter $(n=2)$, grey and white matter of the thalamus $(n=3)$ and brainstem $(n=5)$, and at the TNG- 
Table 2. Hematological and biochemical findings of cattle with thrombotic meningoencephalitis

\begin{tabular}{|c|c|c|c|c|c|c|}
\hline \multirow[t]{2}{*}{ Laboratory Parameters } & \multirow{2}{*}{$\begin{array}{l}\text { Reference } \\
\text { values }\end{array}$} & \multicolumn{5}{|c|}{ Animals $\mathrm{n}^{0}$} \\
\hline & & 1 & 2 & 3 & 4 & 5 \\
\hline \multicolumn{7}{|l|}{ Hemogram } \\
\hline Packed Cell Volume (\%) & $27-48$ & 42.8 & 36.8 & 44.1 & 42.1 & 38.0 \\
\hline Red Blood cells $\left(\times 10^{6} / \mu \mathrm{L}\right)$ & $6-11.6$ & 8.51 & 8.20 & 7.88 & 7.6 & 7.97 \\
\hline Hemoglobin $(\mathrm{g} / \mathrm{dL})$ & $8.50-16.5$ & 11.2 & 11.1 & 11.1 & 10.7 & 12.6 \\
\hline Total plasma protein $(\mathrm{g} / \mathrm{dL})$ & $6.6-7.8$ & 7.8 & 7.0 & 8.0 & 9.8 & 7.4 \\
\hline Fibrinogen $(\mathrm{mg} / \mathrm{dL})$ & $300-700$ & 400 & 400 & 1,000 & 800 & 600 \\
\hline Leucocytes $\left(\mathrm{x} 10^{3} / \mu \mathrm{L}\right)$ & $6,200-12,200$ & 10,100 & 14,200 & 8,800 & 7,600 & 7,000 \\
\hline Lymphocytes $\left(\mathrm{x} 10^{3} / \mu \mathrm{L}\right)$ & $3,300-8,000$ & 4,141 & 5,112 & 1,496 & 1,672 & 2,030 \\
\hline Eosinophils $\left(\times 10^{3} / \mu \mathrm{L}\right)$ & $0-2,400$ & 0 & 0 & 0 & 0 & 0 \\
\hline Monocytes $\left(\mathrm{x} 10^{3} / \mu \mathrm{L}\right)$ & $200-700$ & 0 & 284 & 0 & 0 & 0 \\
\hline Bastonetes $\left(\mathrm{x} 10^{3} / \mu \mathrm{L}\right)$ & $0-200$ & 0 & 0 & 88 & 304 & 0 \\
\hline Segmented neutrophils $\left(\mathrm{x} 10^{3} / \mu \mathrm{L}\right)$ & $1,300-3,400$ & 5,959 & 8,804 & 7,216 & 5,624 & 4,970 \\
\hline $\operatorname{MCV}(\mathrm{fL})$ & $30.5-55.5$ & 50.3 & 44.9 & 56.0 & 55.5 & 47.6 \\
\hline MCHC (\%) & $28-38$ & 26.1 & 30.1 & 35.1 & 25.4 & 34.0 \\
\hline $\mathrm{MCH}(\mathrm{pg})$ & $9.7-19$ & 13.1 & 13.5 & 14.0 & 14.0 & 15.8 \\
\hline \multicolumn{7}{|l|}{ Serum biochemistry } \\
\hline Albumin (g/dL) & $2.7-4.3$ & 2.3 & 1.5 & 2.6 & 2.3 & 2.6 \\
\hline Creatinine $(\mathrm{mg} / \mathrm{dL})$ & $1-2.7$ & 2.7 & 0.60 & 1.5 & 1.2 & 2.3 \\
\hline Urea $(\mathrm{mg} / \mathrm{dL})$ & $5.8-35.9$ & 111 & 15 & 35 & 39 & 70 \\
\hline Creatine kinase, CK (UI/L) & $35-280$ & 952 & 136 & 4,117 & 4,164 & 5,676 \\
\hline Aspartate aminotransferase, AST (UI/L) & $32-71$ & 207 & 88 & 962 & 399 & ND \\
\hline Gamma-glutamyl transferase GGT (UI/L) & $3.7-31.3$ & 34 & 45 & 23 & 41 & 30 \\
\hline Alkaline phosphatase, ALP (UI/L) & $33-100$ & 256 & 160 & ND & ND & 198 \\
\hline Total bilirubin $(\mathrm{mg} / \mathrm{dL})$ & $0.32-0.74$ & 0.47 & 0.55 & 0.54 & 0.22 & 0.47 \\
\hline Conjugated bilirubin (mg/dL) & $0.01-0.34$ & 0.35 & 0.35 & 0.12 & 0.05 & 0.06 \\
\hline Unconjugated bilirubin (mg/dL) & $0.16-0.67$ & 0.12 & 0.20 & 0.42 & 0.17 & 0.41 \\
\hline
\end{tabular}

Table 3. Cerebrospinal fluid analyses of cattle with thrombotic meningoencephalitis

\begin{tabular}{|c|c|c|c|c|c|c|}
\hline \multirow[t]{2}{*}{ Parameters } & \multirow{2}{*}{$\begin{array}{c}\text { Reference } \\
\text { values }\end{array}$} & \multicolumn{5}{|c|}{ Animals } \\
\hline & & 1 & 2 & 3 & 4 & 5 \\
\hline \multirow[t]{2}{*}{ Color } & Unco- & Unco- & Unco- & Unco- & Unco- & Unco- \\
\hline & lored & lored & lored & lored & lored & lored \\
\hline Aspect & & Clear & Clear & Clear & Clear & Clear \\
\hline Protein $(\mathrm{mg} / \mathrm{dL})$ & 40 & 39.3 & 21.6 & 19.9 & 17.7 & 133.7 \\
\hline Density & $>1,010$ & 1,004 & 1,008 & 1,006 & 1,006 & 1,004 \\
\hline $\begin{array}{l}\text { Total nucleated } \\
\text { cell count }\left(\mathrm{mm}^{3}\right)\end{array}$ & 10 & 2 & 0 & 0 & 2 & 14 \\
\hline $\begin{array}{l}\text { Segmented } \\
\text { neutrophils (\%) }\end{array}$ & & 0 & 0 & 0 & 0 & 28 \\
\hline $\begin{array}{l}\text { Band } \\
\text { neutrophils (\%) }\end{array}$ & & 0 & 0 & 0 & 0 & 0 \\
\hline $\begin{array}{l}\text { Mononuclear } \\
\text { cells (\%) }\end{array}$ & & 0 & 0 & 0 & 0 & 72 \\
\hline
\end{tabular}

-CRM complex $(n=5)$. Thrombi consisted of discrete intravascular accumulations of neutrophils and/or lymphocytes admixed with fibrin and moderate to marked proliferation of the affected vascular endothelium; intralesional bacteria were not frequently observed and there was no associated perivascular inflammatory exudate. Additionally, varying degrees of cortical edema, gliosis, and hemorrhage were observed in the brain sections evaluated. Other significant non-neurological pathological alterations included thrombi within small vessels of the lung (Fig.1F), myocardium ( $\mathrm{n}^{\circ}$ 2 and 5), liver and intestine ( $\mathrm{n}^{\circ}$ 5).

\section{PCR, sequencing, and phylogenetic analysis}

The H. somni PCR successfully amplified bacterial DNA from the brain of all animals with histopathological dia- gnosis of TME (Table 4). Bacterial DNA was amplified from multiple sections of the brain from all animals, except no 2 , who had H. somni DNA identified only from the trigeminal nerve ganglion. In summary, $H$. somni DNA was amplified from the TNG-CRM complex $(n=5)$, thalamus $(n=4)$, the brainstem and cerebral cortex $(n=3)$, and cerebellum $(n=2)$ of affected animals. All other PCR/RT-PCR assays provided negative results and all animals were negative for rabies virus by the immunofluorescence assay.

Direct sequencing revealed the desired 408 base pairs of the partial nucleotide sequence of the $H$. somni 16 rRNA gene from the TNG-CRM complex (animals $\mathrm{n}^{\circ}$ 1, 2, and 4 ), cerebral cortex (no 3 ), and the brainstem (no 5 ). Initial BLAST analyses revealed that all nucleotide sequences (GenBank Accession no KM374589, animal no 1; KM374590, no 2; KM374591, n 3; KM374592, no 4; and KM374593, no 5) derived from this study demonstrated $99-100 \%$ identity with similar sequences deposited in GenBank. Further, the generated phylogenetic tree revealed that all isolates of $H$. somni formed a large cluster, which was distinct from other members of the Pasteurellaceae family (Fig. 2).

\section{DISCUSSION}

The histopathological findings observed within several brain sections of these animals are consistent with those described in H. somni-induced TME of ruminants (Fecteau \& George 2004; Maxie \& Youssef 2007; George 2009), and similar to the brain lesions previously described in cases of systemic (Headley et al. 2013b) and reproductive (Headley et al. 2015) histophilosis from Brazil. Additionally, the amplification and consequent sequencing of $\mathrm{H}$. somni from these 


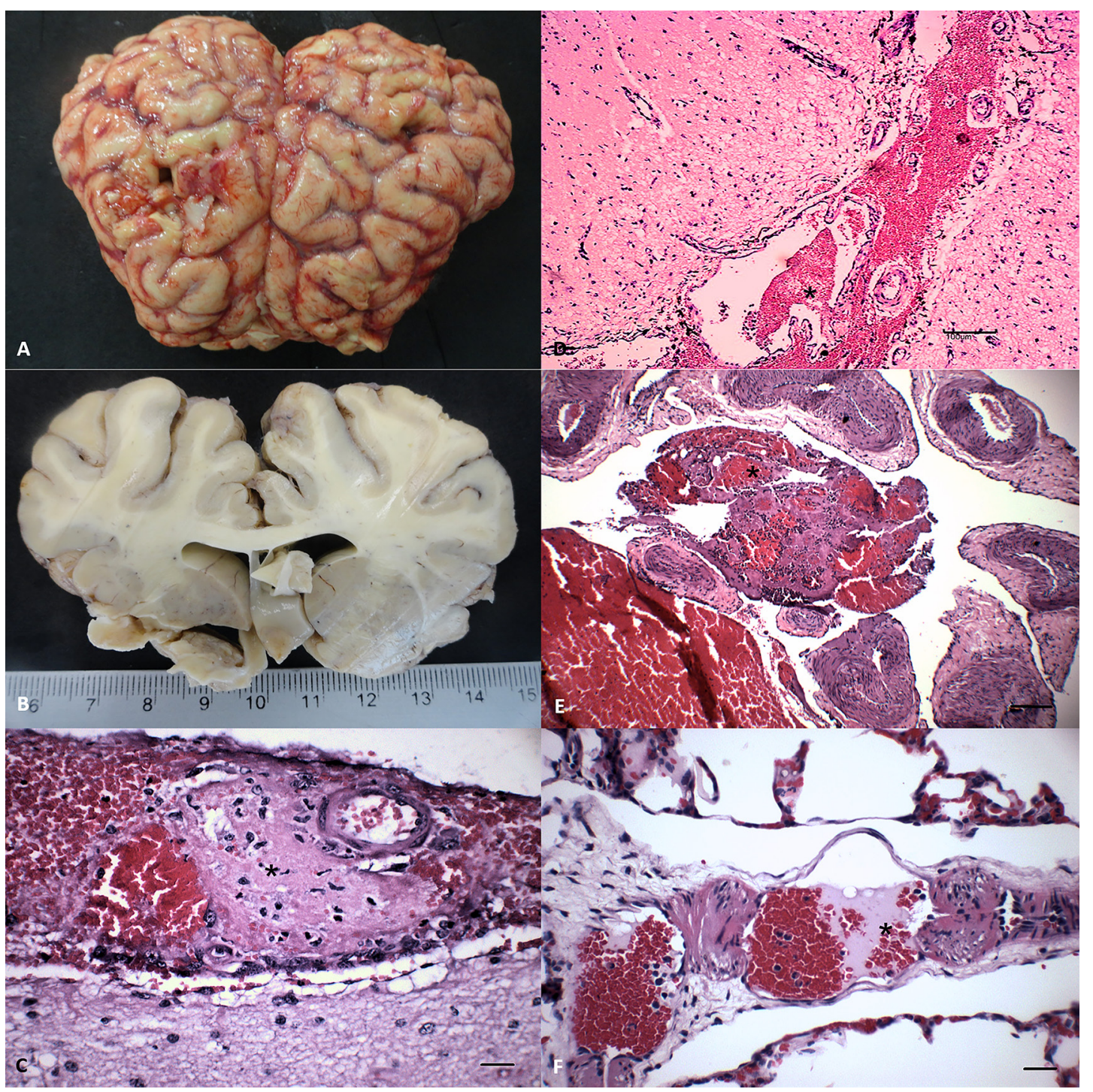

Fig.1. Gross and histopathological features of Histophilus somni induced thrombotic meningoencephalitis in cattle from northern Paraná.

(A) Congestion of meningeal vessels and hemorrhage with distended gyri and shallow sulci. (B) Edema of the sectioned surface of the cerebrum. There are thrombi $\left({ }^{*}\right)$ at the meninges (C-D), carotid rete miriabile (E), and the lungs (F). (B) Scale in centimeters. (CF) Hematoxylin and eosin stain. (C and F) Bar $=20 \mu \mathrm{m}$. (D-E) $100 \mu \mathrm{m}$.

Table 4. Principal gross findings with the distribution of thrombotic meningoencephalitis and Histophilus somni DNA in brain sections of cattle

\begin{tabular}{|c|c|c|c|c|c|c|c|c|c|c|c|}
\hline \multirow[t]{2}{*}{ Animal $\mathrm{n}^{0}$} & \multirow[t]{2}{*}{ Gross findings } & \multicolumn{5}{|c|}{ Thrombotic meningoencephalitis } & \multicolumn{5}{|c|}{ Histophilus somni DNA } \\
\hline & & $\begin{array}{l}\text { Brain- } \\
\text { stem }\end{array}$ & $\begin{array}{l}\text { Cere- } \\
\text { bellum }\end{array}$ & $\begin{array}{l}\text { Cere- } \\
\text { brum }\end{array}$ & $\begin{array}{l}\text { TNG- } \\
\text { CRM }\end{array}$ & $\begin{array}{l}\text { Thala- } \\
\text { mus }\end{array}$ & $\begin{array}{l}\text { Brain- } \\
\text { stem }\end{array}$ & $\begin{array}{l}\text { Cere- } \\
\text { bellum }\end{array}$ & $\begin{array}{l}\text { Cere- } \\
\text { brum }\end{array}$ & $\begin{array}{l}\text { TNG- } \\
\text { CRM }\end{array}$ & $\begin{array}{l}\text { Thala- } \\
\text { mus }\end{array}$ \\
\hline 1 & $\begin{array}{l}\text { Congestion of meningeal vessels; } \\
\text { myocardial and endocardial petechial, } \\
\text { hemorrhage, ulcerativeabomastits }\end{array}$ & + & - & + & + & - & + & + & + & + & + \\
\hline 2 & $\begin{array}{l}\text { Cerebrum; shallow sulci with distended gyri; } \\
\text { congestion of meningeal vessels, hydropericardium, } \\
\text { hyperemia of intestinal mucosa }\end{array}$ & + & + & + & + & + & - & - & - & + & - \\
\hline 3 & $\begin{array}{l}\text { Congestion of meningeal vessels, pulmonary } \\
\text { emphysema, and atelectasis, ulcerative abomastits }\end{array}$ & + & - & + & + & + & + & - & + & + & + \\
\hline 4 & $\begin{array}{l}\text { Ascites, cerebrum: shallow sulci with distended } \\
\text { gyri, cranioventral consolidation of lungs, } \\
\text { enlarged liver, hydrothorax, renal infarction, } \\
\text { tongue and oesophagus: ulcerations }\end{array}$ & + & - & + & + & - & - & + & - & + & + \\
\hline 5 & $\begin{array}{l}\text { Significant pathological alterations were } \\
\text { not observed }\end{array}$ & + & + & + & + & + & + & - & + & + & + \\
\hline
\end{tabular}

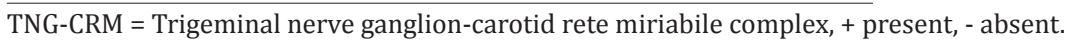




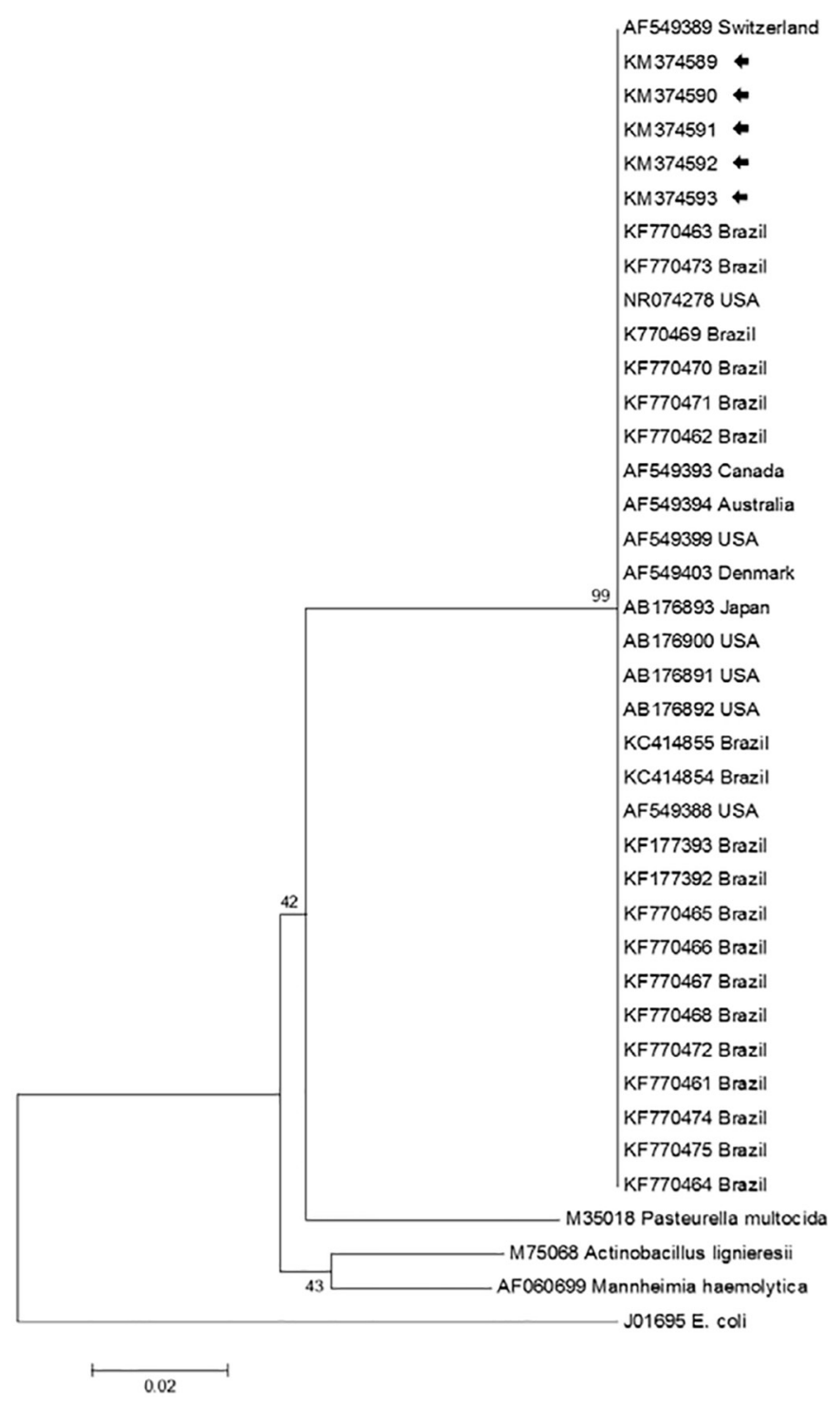

Fig.2. The phylogenetic relationship of selected strains of Histophilus somni based on the $16 \mathrm{~S}$ rRNA gene of the Pasteurellaceae family. The isolates from this study are highlighted (arrows); the GenBank accession numbers and country of origin of the sequences used are given. E. coli was used as the out-group.

areas, suggest that this bacterium was associated with the neuropathological lesions; the amplification of $H$. somni DNA and sequencing were previously used to identify this pathogen (Angen et al. 1998, Headley et al. 2013b, 2015). Moreover, the negative PCRs and RT-PCRs results with the absence of other histopathological disease patterns suggest that other common pathogens associated with neurological disease of cattle were not involved in the development of the clinicopathological manifestations observed during this investigation. Of extreme importance was the negative PCR assay for OvHV-2, since this is a common cause of neurological disease of cattle from Brazil (Headley et al. 2012, 2013c). Additionally, in the cases from this study, lesions at the carotid rete miriabile were thrombotic and not the characteristic fibrinoid necrosis frequently diagnosed in SA-MCF (Headley et al. 2012, 2013c).
The clinical manifestations, the acute incubation period culminating in spontaneous death or euthanasia, and the reduced number of animals affected at each herd during this study are frequent clinical and epidemiological findings associated with TME (MacDonald et al. 1973, Fecteau \& George 2004, George 2009). During this investigation, bacterial isolation was not attempted in any instance since diagnoses of TME were only achieved after histopathological evaluation. It is worthy to mention that the hematological and more specifically, the CSF findings were not indicative of classical bacterial infections of the brain (Scott 2004, Stokol et al. 2009). Although the CBC in cases of TME is nonspecific, the CSF findings normally demonstrate alterations indicative of bacterial disease with an increase in the number of nucleated cells, elevated protein concentrations (Van Dreumel et al. 1970, Fecteau \& George 2004, Scott 2004), xanthochromia, and hemorrhage (Scott 2004). Alterations to CSF levels were only observed in animal no5 but were indicative of hyperproteinorraquia and lymphocytic pleocytosis, without xanthochromia and hemorrhage. Alternatively, a retrospective study that classified the CSF relative to neurological disease in 101 cattle, observed marked variation in the three cases of TME described, with pleocytosis being neutrophilic, lymphocytic, and histiocytic (Stokol et al. 2009). Interestingly, the biochemical alterations observed in most animals are due to prolonged recumbency. However, the results of the CSF presented in this study are important for the ante-mortem diagnosis and the understanding of TME, since there are few documentations of the alterations associated with CSF in spontaneous cases of neurological histophilosis and the classical representation of CSF alterations in TME is not fully known (Scott 2004).

The distribution of TME was predominant at the brainstem, cerebral cortex, and the TNG-CRM complex of all animals, while these lesions were not consistent at the cerebellum and thalamus. However, H. somni DNA was recovered more frequently from the TGN-CRM complex, followed by the thalamus $(n=4)$, cerebral cortex, brainstem $(n=3)$, and cerebellum $(n=2)$. This might suggest that there is no definite correlation between the demonstration of TME in a particular anatomical region of the brain and the amplification of $H$. somni DNA from these areas. Nevertheless, histopathological lesions of TME seem to have predilection for the cerebral cortex (MacDonald et al. 1973, Maxie \& Youssef 2007, Zachary 2012) and thalamus (Maxie \& Youssef 2007), but can be randomly distributed throughout any part of the brain (MacDonald et al. 1973). These findings are in agreement with the distribution of TME observed during this investigation, and suggest that fragments of multiple anatomical regions of the brain must be collected to obtain an accurate histopathological diagnosis of TME, particularly in non-conventional areas of this disease. Additionally, since histopathological confirmation and the amplification of $H$. somni DNA was constant from the TGN-CRM complex of all animals, this neuroanatomical region, of the brain, particularly the carotid rete miriabile, should always be investigated when TME is suspected. 
The identification of $H$. somni DNA from these cases with typical histopathological findings of TME represent the first successfully characterization of this important neurological disease of cattle from Brazil, and definitely extends the geographical distribution of this disease and pathogen. This is because histophilosis was previously described by our group in cattle from southern Brazil (Headley et al. 2013b), while the bacterium has been associated with steers that demonstrated pulmonary distress at a feedlot (Headley et al. 2014a), and in sheep with endometritis (Rizzo et al. 2012). In addition, H. somni has been linked to abortions in cattle from different geographical regions of Brazil (Headley et al. 2015). Further, H. somni DNA was identified from the bronquialveolar lavage of cattle with and without pulmonary discomfort (Oliveira et al., manuscript in preparation), and in a lamb with omphalitis (Headley et al., manuscript in preparation). Interestingly, vaccination of cattle against $H$. somni is not a routine practice in beef and dairy cattle herds of Brazil, so additional cases of histophilosis are likely to occur nationwide. Consequently, this disease might be a possible threat to the local cattle industry (Headley et al. 2014a), resulting in serious economic losses as have been documented in North America (Saunders et al. 1980). However, since the distribution of H. somni in cattle herds of Brazil is unknown, seroepidemiological studies are being implemented to determine the prevalence of this pathogen in beef and dairy herds.

\section{CONCLUSIONS}

Histophilus somni DNA was identified from brain fragments of cattle with neuropathological manifestations and histopathological lesions that are consistent with those described in TME of cattle from North America.

Further, sequencing of the H. somni 16S rRNA gene from affected brain fragments of all animals confirmed the participation of this pathogen in the lesions herein described.

These results contribute to the documentation of this important emerging infectious disease of cattle from Brazil and South America, complements previous findings of histophilosis by our group (Headley et al. 2013b, 2014a, 2015), and produces novel CSF findings associated with spontaneous cases of TME.

Acknowledgements.- Selwyn A. Headley, Ana Paula F.R.L. Bracarense, Alice F. Alfieri, Júlio A.N. Lisbôa, and Amauri A. Alfieri are recipients of the National Council for Scientific and Technological Development (CNPq, Brazil) fellowships. This study was partially funded by a CNPq grant (Proposal \#448797/2014-3) and a joint CNPq/Ministry of Agriculture (MAPA) grant (Protocols \#578645/2008-4 and \#478254/2012-1).

The authors contributed for publication of the article as follows: SAH and AAA: conceived and designed the study;

SAH, APFRB and WO: were involved in the pathological evaluations and interpretations;

SAH, VHSO, AFA and AAA: participated in the molecular analyses and interpretations;

GRQ and JANL: did the clinical and neurological examinations and visited the farms;

KKMC and JANL: were responsible for the clinical laboratiory investigation;

All authors participated in the drafting of the manuscript, read, and approved the final version.

\section{REFERENCES}

Alfieri A.A., Parazzi M.E., Takiuchi E., Medici K.C. \& Alfieri A.F. 2006. Frequency of group A rotavirus in diarrhoeic calves in Brazilian cattle herds, 1998-2002. Trop. Anim. Health Prod. 38:521-526.

Angen O., Ahrens P. \& Tegtmeier C. 1998. Development of a PCR test for identification of Haemophilus somnus in pure and mixed cultures. Vet. Microbiol. 63:39-48.

Baxter S.I., Pow I., Bridgen A. \& Reid H.W. 1993. PCR detection of the sheep-associated agent of malignant catarrhal fever. Archs Virol. 132: 145-159.

Boom R., Sol C.J., Salimans M.M., Jansen C.L., Wertheim-Van Dillen P.M. \& Van der Noordaa J. 1990. Rapid and simple method for purification of nucleic acids. J. Clin. Microbiol. 28:495-503.

Claus M.P., Alfieri A.F., Folgueras-Flatschart A.V., Wosiacki S.R., Medici K.C. \& Alfieri A.A. 2005. Rapid detection and differentiation of bovine herpesvirus 1 and 5 glycoprotein $C$ gene in clinical specimens by multiplex-PCR. J. Virol. Methods 128:183-188.

Descarga C.O., Piscitelli H.G., Zielinski G.C. \& Cipolla A.L. 2002. Thromboembolic meningoencephalitis due to Haemophilus somnus in feedlot cattle in Argentina. Vet. Rec. 150:817.

Fecteau G. \& George L.W. 2004. Bacterial meningitis and encephalitis in ruminants. Vet. Clin. North. Am., Food. Anim. Pract. 20:363-377.

George L.W. 2009. Thrombotic meningoencephalitis (Histophilus somni [Haemophilus somuns] infection; sleeper calves), p.1048-1050. In: Smith B.P. (Ed.), Large Animal Internal Medicine. Mosby/Elsevier, St Louis, Missouri.

Headley S.A., Sousa I.K.F., Minervino A.H.H., Barros I.O., Barrêto Júnior R.A., Alfieri A.F., Ortolani E.L. \& Alfieri A.A. 2012. Molecular confirmation of ovine herpesvirus 2-induced malignant catarrhal fever lesions in cattle from Rio Grande do Norte, Brazil. Pesq. Vet. Bras. 32:1213-1218.

Headley S.A., Bodnar L., Fritzen J.T., Bronkhorst D.E., Alfieri A.F., Okano W. \& Alfieri A.A. 2013a. Histopathological and molecular characterization of encephalitic listeriosis in small ruminants from northern Parana, Brazil. Braz. J. Microbiol. 44:889-896.

Headley S.A., Oliveira V.H., Figueira G.F., Bronkhorst D.E., Alfieri A.F., Okano W. \& Alfieri A.A. 2013b. Histophilus somni-induced infections in cattle from southern Brazil. Trop. Anim. Health Prod. 45:1579-1588.

Headley S.A., Queiroz G.R., Fritzen J.T.T., Lisboa J.A.N., Alfieri A.F., Oliveira R.A.M., Bracarense A.P.F.R.L. \& Alfieri A.A. 2013c. Ovine herpesvirus type 2-induced malignant catarrhal fever in a heifer. Semina, Ciênc. Agrarias 34:3895-3900.

Headley S.A., Alfieri A.F., Oliveira V.H.S., Beuttemmüller E.A. \& Alfieri A.A. 2014a. Histophilus somni is a potential threat to beef cattle feedlots from Brazil. Vet. Rec. 175:249.

Headley S.A., Fritzen J.T.T., Queiroz G.R., Oliveira R.A.M., Alfieri A.F., Santis G.W.D., Lisbôa J.A.N. \& Alfieri A.A. 2014b. Molecular characterization of encephalitic bovine listeriosis from southern Brazil. Trop. Anim. Health Prod. 46:19-25.

Headley S.A., Voltarelli D., Oliveira V.H.S., Bronkhorst D.E., Alfieri A.F., Negri L.C., Okano W. \& Alfieri A.A. 2015. Association of Histophilus somni with spontaneous abortions in dairy cattle herds from Brazil. Trop. Anim. Health Prod. 47:403-413.

Hick P.M., Read A.J., Lugton I., Busfield F., Dawood K.E., Gabor L., Hornitzky M. \& Kirkland P.D. 2012. Coronavirus infection in intensively managed cattle with respiratory disease. Aust. Vet. J. 90:381-386.

Inzana T.J. \& Corbeil L. 2004. Haemophilus, p.243-258. In: Gyles C.L., Prescott J.F., Songer G. \& Thoen C.O. (Eds), Pathogenesis of Bacterial Infections in Animals. Blackwell Publishing, Ames, Iowa.

Lancaster M.J., McGillivery D.J., Patterson R.M. \& Irwin S. 1984. Pneumonia associated with Haemophilus somnus in a calf. Aust. Vet. J. 61:269.

MacDonald D.W., Christian R.G. \& Chalmers G.A. 1973. Infectious thromboembolic meningoencephalitis: literature review and occurrence in Alberta, 1969-71. Can. Vet. J. 14:57-61.

Maxie M.G. \& Youssef S. 2007. Nervous system, p.408-411. In: Maxie M.G. (Ed.), Jubb, Kennedy, and Palmer's Pathology of Domestic Animals, Vol.1. Saunders/Elsevier, Philadelphia. 
Pérez D.S., Pérez F.A. \& Bretschneider G. 2010. Histophilus somni: pathogenecity in cattle an update. An. Vet. Murcia 26:5-21.

Rizzo H., Gregory L., Carvalho A.F. \& Pinheiro E.S. 2012. Histophilus somni isolation on sheep with endometritis first case report on Brazil. Revta Bras. Reprod. Anim. 36:136-138.

Saunders J.R., Thiessen W.A. \& Janzen E.D. 1980. Haemophilus somnus infections I. A ten year (1969-1978) retrospective study of losses in cattle herds in Western Canada. Can. Vet. J. 21:119-123.

Scott P.R. 2004. Diagnostic techniques and clinicopathologic findings in ruminant neurologic disease. Vet. Clin. North Am., Food Anim. Pract. 20: 215-230.

Stokol T., Divers T.J., Arrigan J.W. \& McDonough S.P. 2009. Cerebrospinal fluid findings in cattle with central nervous system disorders: a retrospective study of 102 cases (1990-2008). Vet. Clin. Pathol. 38:103-112.

Tamura K., Peterson D., Peterson N., Stecher G., Nei M. \& Kumar S. 2011. MEGA5: molecular evolutionary genetics analysis using maximum likelihood, evolutionary distance, and maximum parsimony methods. Mol. Biol. Evol. 28:2731-2739.
Tanaka A., Hoshinoo K., Hoshino T. \& Tagawa Y. 2005. Differentiation between bovine and ovine strains of Histophilus somni based on the sequences of 16S rDNA and rpoB gene. J. Vet. Med. Sci. 67:255-262.

Van Dreumel A.A., Curtis R.A. \& Ruhnke H.L. 1970. Infectious thromboembolic meningoencephalitis in Ontario feedlot cattle. Can. Vet. J. 11:125130.

Vilček Š., Herring A.J., Herring J.A., Nettleton P.F., Lowings J.P. \& Paton D.J. 1994. Pestiviruses isolated from pigs, cattle and sheep can be allocated into at least three genogroups using polymerase chain reaction and restriction endonuclease analysis. Archs Virol. 136:309-323.

Wesley I.V., Larson D.J., Harmon K.M., Luchansky J.B. \& Schwartz A.R. 2002. A case report of sporadic ovine listerial menigoencephalitis in Iowa with an overview of livestock and human cases. J. Vet. Diagn. Invest. 14:314-321.

Wessels J. \& Wessels M.E. 2005. Histophilus somni myocarditis in a beef rearing calf in the United Kingdom. Vet. Rec. 157:420-421.

Zachary J.F. 2012. Nervous system, p.771-870. In: Zachary J.F. \& McGavin M.D. (Eds), Pathological Basis of Veterinary Disease. Elsevier/Mosby, St Louis, Missouri.1322p. 